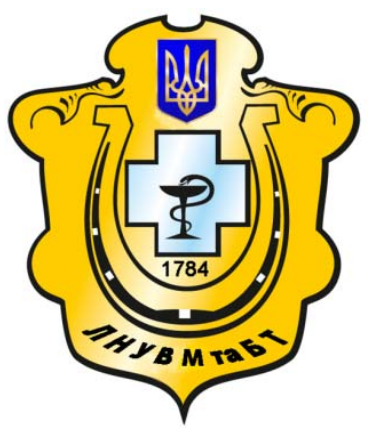

Науковий вісник Львівського національного університету ветеринарної медицини та біотехнологій імені С.3. Гжицького

Scientific Messenger of Lviv National University of Veterinary Medicine and Biotechnologies named after S.Z. Gzhytskyj

doi:10.15421/nvlvet6921

ISSN 2413-5550 print

ISSN 2518-1327 online

$\underline{\text { http://nvlvet.com.ua/ }}$

УДК 338.43:334.72

\title{
Діагностика проблем державної регуляторної політики у агропромисловій сфері вітчизняної економіки
}

\author{
Т.Т. Небоженко \\ nebozhenko008@gmail.com
}

\begin{abstract}
Львівський національний університет ветеринарної медицини та біотехнологій імені С.3. Гжиџького, вул. Пекарська, 50, м. Львів, 79010, Украӥна
\end{abstract}

Доведено необхідність та значимість державного регулювання функціонування суб 'єктів господарювання агропромислової сфери. Виявлено проблеми державної регуляторної політики у агропромисловій сфері вітчизняної економіки та окреслено перелік напрямків їх усунення. Проведено дослідження сучасного стану державного регулювання функиіонування суб 'єктів аграрної сфери та його впливу на розвиток сільськогосподарських підприємств в Украӥні. Конкретизовано функиії державного регулювання сільського господарства. Охарактеризовано організаційно-правові форми підприсмництва, які використовуються в сільському господарстві Украйни. Проаналізовані різні види підприємств, щяо провадять свою діяльність у сільськогосподарській сфері. Наголошено на необхідності законодавчого закріплення основоположних принципів державної підтримки сільськогосподарських товаровиробників, такі як системність і стабільність. Доведено необхідність державного регулювання функиіонування підприємницьких структур у сільському господарстві. Проідентифікувались теоретичні й загальнометодологічні проблеми держсавного регулювання організаційно-правових форм сільськогосподарських підприємств. Деталізувалися правові проблеми державного регулювання сільського господарства в Україні. Обтрунтовано недостатню ефективність державної політики щодо створення умов формування кооперативних та інших некомериійних об'єднань сільськогосподарських підприємств у сфері виробництва та збуту сільськогосподарської продукиії. Проводиться виявлення недоліків у організаиії та регулюванні агропромислового виробниитва в Україні.

Ключові слова: державне регулювання, державна підтримка, регуляторна політика, сільське господарство, агропромисловий комплекс.

\section{Диагностика проблем государственной регуляторной политики в агропро- мышленной сфере отечественной экономики}

\author{
T.Т. Небоженко \\ nebozhenko008@gmail.com
}

Львовский национальный университет ветеринарной медииины и биотехнологий имени С.3. Гюицкого, ул. Пекарская, 50, г. Львов, 79010, Украина

Доказана необходимость и значимость государственного регулирования функционирования субъектов хозяйствования агропромышленной сферы. Выявлены проблемы государственной регуляторной политики в агропромышленной сфере отечественной экономики и очерчены перечень направлений их устранения. Проведено исследование современного состояния государственного регулирования функиионирования субъектов аграрной сферы и его влияния на развитие сельскохозяйственных предприятий в Украине. Конкретизированы функиии государственного регулирования сельского хозяйства.

Охарактеризованы организачионно-правовые формы предпринимательства, используемых в сельском хозяйстве Украины. Проанализированы различные виды предприятий, осуществляющих свою деятельность в сельскохозяйственной сфере.

Отмечены основные принципь государственной поддержки сельскохозяйственных товаропроизводителей. Доказана необходимость государственного регулирования функционирования предпринимательских структур в сельском хозяйстве

Citation:

Nebozhenko, T.T. (2016). Diagnosis of state regulatory policy issues in agricultural industry of national economy. Scientific Messenger LNUVMBT named after S.Z. Gzhytskyj, 18, 2(69), 107-112. 
Проидентифицырывались теоретические и общеметодологические проблемы государственного регулирования организачионно-правовых форм сельскохозяйственных предприятий. Детализировались правовые проблемы государственного регулирования сельского хозяйства в Украине. Обоснованно недостаточная эффективность государственной политики по созданию условий формирования кооперативных и других некоммерческих объединений сельскохозяйственных предприятий в сфере производства и сбыта сельскохозяйственной продукции.

Выявлялись недостатки в организации и регулировании агропромышленного производства в Украине.

Ключевые слова: государственное регулирование, государственная поддержка, регуляторная политика, сельское хозяйство, агропромышленный комплекс.

\title{
Diagnosis of state regulatory policy issues in agricultural industry of national economy
}

\author{
T.T. Nebozhenko \\ nebozhenko008@gmail.com

\begin{abstract}
Lviv National University of Veterinary Medicine and Biotechnologies named after S.Z. Gzhytskyi, Pekarska Str., 50, Lviv, 79010, Ukraine
\end{abstract}

\begin{abstract}
The necessity and importance of state regulation of the business entities of agro-industrial sector. The problems of regulatory policy in the agro-industrial sector of the national economy and outlines directions for their removal. A study of the current state of state regulation of the functioning of the agricultural sector and its impact on the development of agricultural enterprises in Ukraine. Concretized functions of state regulation of agriculture. Characterized legal forms of business that are used in agriculture Ukraine.Analyzed different types of companies that conduct their activities in the agricultural sector. The necessity of the law on the fundamental principles of state support for agricultural producers, such as consistency and stability. The necessity of state regulation of the operation of businesses in agriculture. Identified general methodological and theoretical problems of state regulation of legal forms of agricultural enterprises. Detailed legal problems of state regulation of agriculture in Ukraine.

Grounded lack of effectiveness of public policies to create conditions for the formation of cooperative associations and other non-commercial agricultural enterprises in the production and marketing of agricultural products. State regulation of agriculture structures must be in compliance with the principles of stability and consistency. This will require a clearly defined action plan, program, and which will provide various types of state support for agricultural enterprises. A discovery of defects in the organization and regulation of agricultural production in Ukraine.
\end{abstract}

Key words: government regulation, government support, regulatory policy, agriculture, agro-industrial complex.

\section{Вступ}

Сільське господарство, незалежно від методів його організації, національної приналежності, форм власності, рівня розвитку, має свої властиві лише йому специфічні, особливості, що відрізняють його від усіх інших галузей народногосподарського комплексу. Ці особливості головним чином проявляються в умовах ринкової економіки при вільній конкуренції і слабкому рівні державного регулювання процесів, що відбуваються. У результаті цього в більшості країн світу не тільки визнана необхідність державного втручання в рівень розвитку сільського господарства, а й прийняті конкретні нормативні акти, на основі яких вироблені ефективні напрямки, програми, що забезпечують сталий розвиток не тільки галузей сільськогосподарського виробництва, а й усіх сфер діяльності та умов проживання сільського населення.

Враховуючи всі перелічені вище особливості, а також необхідність розвитку агропромислового комплексу в різних країнах, в аграрній політиці багатьох європейських держав побудовані теоретичні моделі, на основі яких визначені закономірності і необхідність державного регулювання економіки агропромислового комплексу i, в першу чергу, сільськогосподарського виробництва, які на практиці широко використовуються. Державні органи влади у всіх розвинених країнах за допомогою різних економічних і фінансових дій та прийомів (в тому числі системою бюджетування, дотацій і компенсацій, введенням спеціальної системи оподаткування, зниженням тарифів на споживані сільським господарством ресурси, системою кредитування і страхування з компенсацією 3 бюджету i т. д.) здійснюють постійну підтримку сільського господарства шляхом перерозподілу доходів з різних галузей економіки. Проте в Україні державна регуляторна політика агропромислового комплексу носить фрагментарний та неефективний характер, і не виконує усіх завдань, реалізація яких $\epsilon$ необхідною для стабільного функціонування підприємств сільського господарства.

Метою роботи було виявити проблеми державної регуляторної політики у агропромисловій сфері та запропонувати шляхи їх усунення.

Аналіз останніх наукових досліджень та публікаuій. Питанням визначення особливостей та сучасного стану механізму державного регулювання діяльності підприємств агропромислової сфери присвячені численні праці сучасних вчених. Зокрема, вітчизняні дослідники, наприклад, А.В. Безкровний та О. В. Клєпчева вивчають аспекти впливу державного регулювання на ефективність сільськогосподарського виробництва та роль державного регулювання в забезпеченні економічної стійкості сільськогосподарських підприємств (Bezkrovnyj, 2013; Kljepcheva, 2013); Не оминули увагою ці та інші аспекти, пов'язані із державною регуляторною політикою сільськогосподарських товаровиробників, і зарубіжні науковці. Зокрема, В.В. Бут, I.О. Сорокіна конкретизували проблеми державної підтримки сільського господарства у Росії 
(But and Sorokina, 2011), Е.С. Мезенцева детально дослідила зміст державного регулювання сільськогосподарського виробництва (Mezenceva, 2009), B.I. Нечаєв узагальнив регіональні аспекти державного регулювання агропромислового виробництва (Nechaev et al., 2009), Л.В. Сорокіна довела, що аграрний протекціонізм має стати принципом державного регулювання сільськогосподарського виробництва (Sorokina, 2012). Проте, комплексних сучасних досліджень, які б узагальнювали існуючі проблеми державної регуляторної політики у агропромисловій сфері економіки України та містили пропозиції щодо їх вирішення у процесі аналізу останніх досліджень публікацій у даній науковій царині на разі виявлено не було.

\section{Результати та їх обговорення}

Необхідність створення в механізму державного регулювання агропромислового комплексу (АПК) випливає 3 місця і ролі цього сектора в ринковій економіці України. Зокрема, АПК не може на рівних брати участь в міжгалузевої конкуренції. Сільське господарство залежить від природних чинників, має яскраво виражений сезонний характер виробництва, низьку віддачу вкладеного капіталу, а рівень сільськогосподарського виробництва впливає на стан продовольчої безпеки країни.

Державне регулювання являє собою комплекс певних стимулів, за допомогою яких держава бере участь у ринкових процесах на правах суб'єкта ринкових відносин, забезпечуючи сталий розвиток агропромислового виробництва. Державне регулювання аграрної сфери економіки полягає у тому, що держава шляхом застосування правових, адміністративних та економічних важелів регулює поведінку сільськогосподарського товаровиробника, визначає перспективи розвитку агарної сфери економіки, виконує спрямовуючу роль щодо реалізації довготривалих програм розвитку (Maslova, 2011; Komarova, 2013; Martynjuk, 2014).

$€$ дві фундаментальні причини використання інституту державного регулювання щодо сільського господарства. Одна полягає в тому, що державне регулювання вводиться й існує в умовах, коли держава, суспільство і національне господарство може отримати від його продуктів деяку вигоду. Розмір вигоди, iіi співвідношення 3 вигодою, яку дані інститути отримують від інших видів діяльності і галузей, визначає форми і види взаємодії держави з сільським господарством.

Виходячи 3 даного узагальнення, можна зробити наступний висновок: форма, вид, а також розмір державного впливу на сільське господарство обернено пропорційні вигодам, які отримують суспільство, держава i національне господарство від нього при наявності настільки ж високих вигід від інших галузей національної економіки та видів діяльності держави і суспільства. Інший полягає в тому, що державне регулювання по відношенню до сільського господарства вводиться державою, суспільством і його інститутами за умови, якщо втрати від сільського господарства виявляються занадто високими, щоб їх можна було покрити за рахунок вигід, одержуваних від інших галузей і видів діяльності.

Можна виокремити кілька основних напрямків участі держави у регулюванні агропромислової сфери (рис. 1).

Окремі завдання ставляться перед державною регуляторною політикою щодо малих організаційноправових форм сільськогосподарських підприємств. Так, напрямами державного регулювання малого агробізнесу є:

1) інституційна, організаційна, фінансова підтримка фермерських (селянських) господарств;

2) створення i розвиток бізнес-інкубаторів, агентств підтримки малого підприємництва на селі;

3) підтримка виробничої, збутової, кредитної та страхової кооперації;

4) державна участь в інтегрованих формуваннях (агропромислових кластерах, агрохолдингах, в торгово-закупівельній діяльності, агросервісі 3 метою забезпечення державного контролю);

5) організація спільних систем державних закупівель та державних (муніципальних) завдань.

3 рис. 1 можна зробити висновок, що державна регуляторна політика у сільськогосподарській сфері покликана виконати велику кількість важливих завдань для підвищення ефективності економіки країни. Проте, якісне виконання поставлених задач можливе лише за умови раціональної організації державної регуляторної політики. Однак на разі в Україні державна регуляторна політика в аграрній сфері здійснюється без чітких стратегічних цілей. Характерною іiі ознакою $є$ фрагментарність, спрямованість на вирішення окремих часткових проблем, які $є$ симптомами невизначеності загальних цілей, що належить досягнути за результатами державного регуляторного впливу. До основних проблем, характерних для сучасної державної регуляторної політики у агропромисловій сфері вітчизняної економіки, на нашу думку, можна віднести наступні:

- залишення тривалий час поза увагою особистих селянських господарств, які на разі є основними виробниками багатьох видів продукції в Україні;

- невтручання державних органів управління сільським господарством у процеси становлення нових організаційних форм господарювання 3 надією, що такі оптимальні форми будуть сформовані автоматично шляхом еволюційного розвитку. Це призвело до поєднання особливо дрібних за розмірами особистих селянських господарств, які мають історично перехідний характер і не можуть бути прототипом ідеальної форми господарювання на перспективу 3 особливо великими, відірваними від сільських населених пунктів господарств холдингового типу, до роботи у яких, як правило, не залучаються сільські жителі, а кошти від сплати податків акумулюються у великих містах, де такі агрохолдинги зареєстровані, не спрямовуються на становлення соціальної сфери села і розвиток сільських територій;

- допущення монопольного впливу окремих закупівельних організацій на ринок сільськогосподарської продукції, встановлення ними монопольно низьких 
цін на окремі види продукції сільськогосподарського виробництва;

- недосягнення стабілізації ринкових цін, нездатність підтримати рівень зайнятості сільського населення на високому рівні;

- нездатність попередити появу бюджетного дефіциту, зовнішнього боргу або негативного сальдо в зовнішній торгівлі сільськогосподарською продукці$є ю$;

- не забезпечення економічної справедливості у розвитку сільського господарства;

- допущення не рівноправних умов для всіх суб'єктів господарювання у сфері АПК;

- нехтування принципом компліментарності сільського господарства і села (тобто, відсутність закріплення на нормативно-правовому рівні тісного зв'язку між сільським господарством і селом);

- відсутність налагодженої співпраці між аграрним міністерством і громадським сектором; не бажання міністерства передати громадському сектору частину управлінських і контролюючих функцій, відповідно до практики, що довела свою ефективність у країнах $\mathrm{EC}$;

- зловживання Державним агентством земельних ресурсів своїми повноваженнями.

Застосування програмно-цільових підходів до розробки регуляторної політики дозволить вирішити найактуальніші із перерахованих проблем із узгодженням необхідних сум фінансування, визначенням виконавців і термінів виконання. Побудова ієрархії проміжних цілей, спрямованих на наближення стану сільського господарства до очікуваного високого рівня ефективності може базуватись на визначені його стратегічної моделі, попередньому вирішенні тих проблем, які є підгрунтям для вирішення проблем вищого рівня.

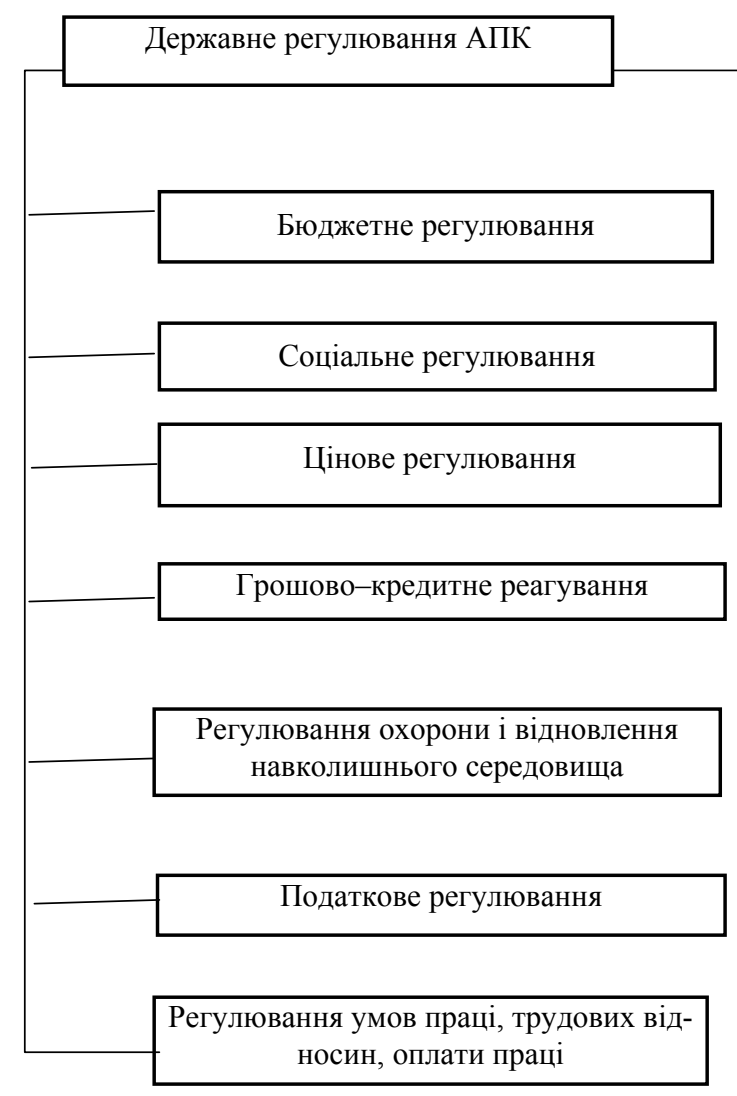

$\rightarrow$\begin{tabular}{c|} 
Державна регуляторна політика у \\
агропромисловій сфері
\end{tabular}
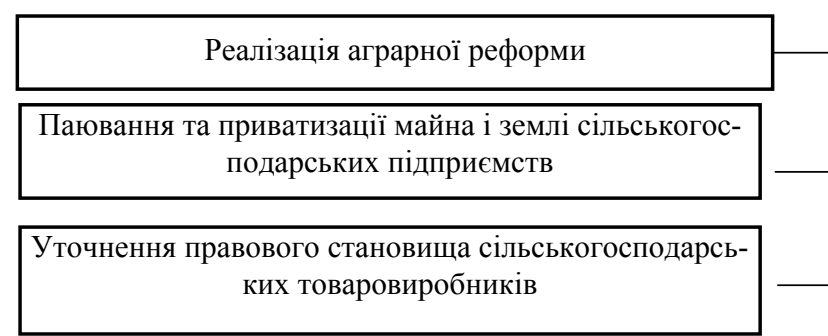

Визначення особливих умов участі сільськогосподарських підприємств у фінансових відносинах

Заходи державної підтримки учасників сільськогосподарського виробництва

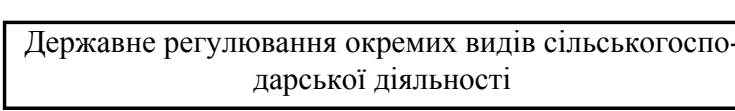
Особливості використання земель сільськогосподарсь- кого призначення

Формування ринкових відносин на договірних засадах

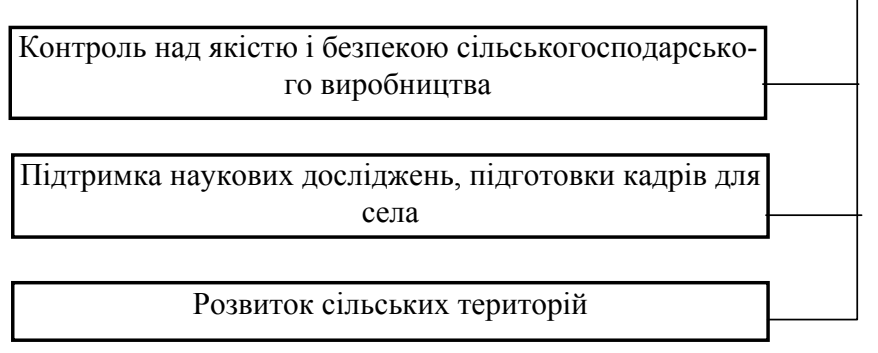

Рис. 1. Напрями здійснення державної регуляторної політики у агропромисловій сфері вітчизняної економіки та основні форми державного регулювання АПК

Складено автором із використанням (Maslova, I.A. (2011). 
В процесі державного регулювання АПК для забезпечення його підтримки в сучасних умовах глобалізації економіки, посилення конкурентної боротьби необхідно виходити зі специфіки соціальнополітичних та економічних умов, балансу податкового, фінансово-кредитного та цінового регулювання, обліку вимог ринку i міжнародних організацій. Рівень компетентності органів управління АПК, готовність організацій до сприйняття встановлених правил, використання наданих їм повноважень, а також наявність i правильне використання наявних ресурсів потребують особливої уваги. Система державної підтримки повинна бути гнучкою, відповідати поточним і довгостроковим потребам АПК (Maslova, 2011; Serbinenko and Serbinenko, 2014).

Організаційно-економічний механізм державного регулювання сільського господарства країни повинен бути орієнтований на збереження і розвиток ресурсів галузі: матеріально-технічних, трудових, земельних, фінансових, інформаційних. Названий механізм повинен включати комплекс впливів, без яких неможливим $\epsilon$ ефективне регулювання агропромислового виробництва. Основними засобами вирішення проблеми (елементами механізму), на наш погляд, слід вважати безпосередньо економічні, юридичні, організаційно-адміністративні.

При розробці напрямів державного регулювання сільського господарства на сучасному етапі в Україні особливого значення набувають принципи соціальної спрямованості реформ та пріоритетності розвитку середовища функціонування. Поєднання і дотримання зазначених принципів є можливим в рамках програмно-цільового підходу до державного регулювання та підтримки сільського господарства.

У сільському господарстві найбільшій деформації в кризовий період піддався людський фактор, що виявилося у знеціненні сільськогосподарської праці; погіршенні демографічної ситуації; скороченні числа робочих місць і рівня зайнятості на селі; звуженні аграрного ринку праці; скороченні об'єктів соціальної інфраструктури, соціально-побутових послуг. Для підготовки сільськогосподарського працівника, схильного до інновацій, освоєння нових технологій, орієнтованого на їх створення, необхідно комплексно здійснити наступні заходи державного регулювання і підтримки:

1) прямі державні інвестиції у розвиток освіти, науки, вдосконалення системи підготовки кваліфікованих кадрів для реалізації інноваційної моделі розвитку сільського господарства;

2) розвиток сільських територій на основі розробки i реалізації комплексних програм державноприватного і муніципальної-приватного партнерства;

3) підтримка зайнятості сільського населення за рахунок розвитку малого агробізнесу та створення його інфраструктури.

Формування нової моделі агроекономіки, що дозволяє максимально використовувати наявний потенціал багатоукладності сільського господарства, можливе лише за державної підтримки розвитку малого агробізнесу - селянських (фермерських) і особистих підсобних господарств.

Для забезпечення ефективного впровадження науково обгрунтованих методів ведення господарства, просування наукомістких технологій у виробництво та створення інформаційного середовища необхідним $\epsilon$ розвиток інформаційно-консультаційних служб (IКC). Метою ІКС в сільському господарстві є підвищення ефективності функціонування та конкурентоспроможності сільськогосподарських підприємств за допомогою надання їм допомоги в прийнятті обгрунтованих економічних рішень, аутсорсингу, аутстаффінгу, пропаганди нововведень і ділового навчання.

Таким чином, на разі існує чимало проблем державної регуляторної політики у агропромисловій сфері вітчизняної економіки, які необхідно вирішити найближчим часом. У іншому випадку не можна вести мову про ефективну організацію та функціонування агропромислового комплексу країни. Запропоновані у роботі напрямки оптимізації державної регуляторної політики у сільськогосподарській сфері можуть суттєво покращити стан вітчизняних сільськогосподарських підприємств, проте для цього необхідно надати їм статусу програми або стратегії розвитку АПК на державному рівні.

\section{Висновки}

Здійснення діагностики проблем державної регуляторної політики у агропромисловій сфері вітчизняної економіки у рамках даної наукової роботи дозволило зробити наступні висновки.

1. Нині виправданим $є$ посилення регулюючого впливу з боку держави на розвиток сільської економіки, та необхідним якнайшвидше впровадження відповідної програми державного регулювання та підтримки цієї важливої галузі.

2. Сучасна державна регуляторна політика у агропромисловій сфері вітчизняної економіки як по своїй суті, та і у процесі своєї реалізації, містить чимало вад та недоліків, усунення яких $є$ необхідним завданням у процесі оптимізації стану сільськогосподарських підприємств в Україні. Основні з них це недостатня увага до надання державної підтримки малим сільськогосподарським підприємствам, допущення нерівних умов функціонування та ведення бізнесу виробниками сільськогосподарської продукції, низький рівень фінансування аграрного сектору та відсутність заходів щодо покращення стану зайнятості сільського населення.

3. Стратегічним завданням державного регулювання сільського господарства має стати формування ефективного та конкурентоспроможного сільськогосподарського виробництва, що забезпечує продовольчу безпеку країни, нарощує експорт сільськогосподарської сировини і продовольства.

4. Перспектива подальших досліджень полягає у розробці та науковому обгрунтуванні конкретного переліку заходів удосконалення стратегічних та тактичних напрямів реалізації державної регуляторної політика у агропромисловій сфері України та формуванні на їх основі програми розвитку сільського гос- 
подарства та різних організаційно-правових форм сільськогосподарських підприємств на найближчі кілька років.

\section{Бібліографічні посилання}

Bezkrovnyj, A.V. (2013). Vplyv derzhavnogo reguljuvannja na efektyvnist' sil's'kogospodars'kogo. Ekonomika APK. 6, 89-91 (in Ukrainian).

Kljepcheva, O.V. (2013). Rol' derzhavnogo reguljuvannja v zabezpechenni ekonomichnoi stijkosti sil's'kogospodars'kyh pidpryjemstv. Zbirnyk naukovyh prac' Tavrijs'kogo derzhavnogo agrotehnologichnogo universytetu. ekonomichni nauky 2(6), 162-170 (in Ukrainian).

Komarova, I.V. (2013). Derzhavne reguljuvannja rozvytku agrarnogo sektoru ekonomiky Ukrai'ny shljahom bjudzhetnoi' pidtrymky sil's'kogospodars'kyh pidpryjemstv. Visnyk Berdjans'kogo universytetu menedzhmentu i biznesu. 3, 115-119 (in Ukrainian).

Martynjuk, I.I. (2014). Derzhavne reguljuvannja rozvytku dribnogo sil's'kogospodars'kogo vyrobnyctva. Naukovyj visnyk NLTU Ukrai'ny. 24(6), 252-257 (in Ukrainian).

Serbinenko, N.V., Serbinenko, K.G. (2014). Transformacija systemy derzhavnogo reguljuvannja agropromyslovogo sektora $\mathrm{v}$ umovah nestabil'nogo zovnishn'ogo seredovyshha. Zbirnyk naukovyh prac' Tavrijs'kogo derzhavnogo agrotehnologichnogo universytetu (ekonomichni nauky). 2, 200-205 (in Ukrainian).
Cyfrova, N.G. (2012). Informacijne zabezpechennja mehanizmu derzhavnogo reguljuvannja agropromyslovogo kompleksu. Naukovi zapysky Nacional'nogo universytetu «Ostroz'ka akademija». Kul'tura i social'ni komunikacii'. 3, 72-78 (in Ukrainian).

But, V.V., Sorokina, I.A. (2011). Problemy gosudarstvennoj podderzhki sel'skogo hozjajstva Agropromyshlennyj kompleks Rossii. Problemy razvitija $\mathrm{v}$ uslovijah modernizacii jekonomiki. Krasnodar. 1, 52-60 (in Russian).

Mezenceva, E.S. (2009). Soderzhanie gosudarstvennogo regulirovanija sel'skohozjajstvennogo proizvodstva. Jelektronnyj resurs. Sbornik nauchnyh trudov GTU. Serija «Jekonomika». 9 (in Russian).

Nechaev, V.I., Bershickij Ju.I., Reznichenko S.M. (2009). Regional'nye aspekty gosudarstvennogo regulirovanija agropromyshlennogo proizvodstva monografija. SPb. Izdatel'stvo «Lan'» (in Russian).

Sorokina, L.V. (2012). Agrarnyj protekcionizm kak princip gosudarstvennogo regulirovanija sel'skohozjajstvennogo proizvodstva. Problemy sovremennoj jekonomiki. materialy II mezhdunar. nauch. konf. Cheljabinsk. Dva komsomol'ca. 65-68 (in Russian).

Maslova, I.A. (2011). Konceptual'nye osnovy gosudarstvennogo regulirovanija razvitija sel'skogo hozjajstva i gosudarstvennoj podderzhki kak istochnika finansirovanija. Jelektronnyj resurs «Upravlencheskij uchet» 4 (in Russian).

Стаття надійшла до редакиії 20.09.2016 